\title{
Technologies Used in Education of Hearing Impaired Individuals
}

\author{
https://doi.org/10.3991/ijet.v13i09.8303 \\ Basak Baglama $\left.{ }^{\bowtie}\right)$, Meltem Haksiz, Huseyin Uzunboylu \\ Near East University, North Cyprus, Turkey \\ basak.baglama@neu.edu.tr
}

\begin{abstract}
It is very important to provide proper and appropriate education for the hearing impaired individuals. Today, it appears that using only traditional teaching methods is not sufficient for the education of hearing-impaired individuals. The use of modern technology makes training for hearing-impaired individuals more useful. Looking at the literature, it is seen that there are a limited number of studies on the comprehensive use of technologies used in the education of hearing impaired individuals. In this context, the aim of this study is to examine the technologies used in the training of hearing impaired individuals. In this study, document analysis method was used as a qualitative research method. The findings of the study were presented as technologies that contribute to the development of academic and linguistic skills of hearing impaired individuals. Prospects for further research and application were given in the light of the findings.
\end{abstract}

Keywords-Hearing impaired, hearing impaired individuals, education, technology

\section{Introduction}

Hearing impaired individuals are located in the category of individuals who need special education [15]. There are various criteria for classifying the hearing impaired. These are made according to the degree of hearing loss, time of occurrence, cause, place, form and longevity. When measuring hearing loss, the degree of hearing loss is determined according to audiological measurements, and they are diagnosed in terms of slight loss, medium loss, further loss, and very late loss [37]. After the hearing impaired individuals have passed the diagnostic and instrumentation process, the training process is starts. Hearing impaired is the ability of the individual to functionally use verbal language in daily life due to a problem in the hearing aid [36]. As a result, verbal communication is blocked. As a result of this inhibition, the hearing impaired individuals are not able to fully acquire the speaking and literacy dimension of their mother tongue. When the characteristics of the individuals who need special education services are examined, it is revealed that their requirements and characteristics are quite different [7]. Hearing impaired individuals can face with many important problems in school achievement and social life [1]. 
One of the areas where individuals need special education due to these needs is technology [11]. Technology is perceived as products with higher quality scientific knowledge and techniques with its present connotation. Along with the rapid development of information technologies, the gaps in the areas where the classical method used for the training of the handicapped are insufficient are filled. The impossible things to do in the classical method are difficult to achieve thanks to these Technologies. In this way, students with disabilities can be educated in a more comfortable way.

Training technologies shorten the duration of instruction, keep interests alive, embody abstract concepts, provide realistic experiences and create more learning desires.

Computers are being used with the aim of improving the academic skills of children with disabilities in special education, supporting many areas of development such as hand-eye coordination, small muscle motor skills, imitation and language development [27]. Computer training programs for general problem-solving skills such as mathematics and literacy skills are also frequently implemented by educators to children with disabilities. Many studies show that computer training programs positively influence academic skills, language, mathematics, literacy, and competence in children with disabilities, improving attention span and learning performance [16]. With computer programs and adapted tools, students with hearing impairments can read materials created on the computer [32]. Computer-assisted instruction is a teaching method that consists of an environment in which learning takes place in the computer environment, a combination of self-learning principles with computer technology, which strengthens the teaching process and student motivation, which the learners can take advantage of according to their own learning speed [17]. Computer-assisted instruction is an environment that enables individualization of education. In computer assisted instruction, computer is used as a tool in teaching a lesson. Students who use instructional software are learning how to use computers at their own pace and ability [3].

Ari and Bayhan [4] found that using software for computer-aided training in special education provides the benefits of ; individualization and self-improvement, immediate feedback, consistent correction process, repetition without pressure, immediate support, step-by-step training, frequent response by children, motivation, development of motor skills and visual motor coordination, reduction of difficulties, intensification, psychological satisfaction and active learning in education. The use of technology in special education will make it easier for teachers to do their job and for individuals who need special education to understand and use the developing technology and to keep up with the innovations and to ensure that the courses show parallelism with technological developments.

One of the innovations that technology has made in the forefront in recent years is Tablet computers. There are mobile communication technologies, mobile phones, smartphones and tablets, including the use of Personal Digital Assitant (PDA). Tablets can connect to wireless networks and other computers [24]. As a result of the studies conducted with tablets, it was determined that tablets were preferred as teaching tools in education. It has been found that the reasons for preference of tablets is that it provides a rich education and training environment for students and teachers, 
which helps students increase their interest and desire in the lesson, helps their learning [2-9-18-19]. These students and teachers should receive continuous support and training according to their competencies in using Tablet PC to overcome the difficulties of using technology [33]. Teachers' views on the use of tablet computers indicate that tablet computers should be used when teaching target skills, teaching self-care skills, gaining independence skills and applying for awards in visual applications [20]. In another research, in the proposals related to educational tools, teachers emphasized the importance of visual education tools for the students with hearing impairment; and the use of technological educational tools such as computer-internet, television, video cassettes and computer floppy disks. Similarly, Tassel-Baska et al. [35] suggest that technology should be integrated into training programs. In Gersten and Baker [14], the use of technology in training applications has been shown to increase success.

As it is known, Individualized Education Programs of special needs individuals should be assessed by preparing a realistic timetable. An assessment of assistive technologies that are used by special needs individuals or that they will use in the future should be an integral part of the IEP [31]. At least one person in the IEP team needs to be knowledgeable about assistive technology. It is important that at least one person from the IEP team present resources to the meeting via books, catalogs, or internet sites, in order to find out which auxiliary technologies are available or which auxiliary technologies are needed. To be able to provide assistive technology devices or services, the IEP team must have adequate knowledge regarding how this technology will be obtained, how it will be used and how it will be evaluated. At the basic level to be able to make an assessment in IEP meetings on assistive Technologies the evaluation can be listed as; the identification of the needs of the student, the learning of the students about how the assistive technologies should be used, the education of the family members and the staff, the determination of how and where to provide technical assistance on the use of assistive technologies, the identification of other support for adaptation or replacement of assistive technologies and the evaluation of the functionality of assistive technologies [31].

Individuals with hearing impairment who have a separate prescription among disabled people due to hearing loss experience a lot of problems during the education and training process. As children born with hearing loss do not acquire linguistic and speech skills due to various reasons such as not hearing enough voices, not perceiving verbal stimuli, and being deprived of use of the mother language everyday these students are at least five years behind in terms of learning. Providing technology support to schools of hearing impairment individuals so that the problems experienced in hearing impaired education can be improved, and the rapid rise in educational technologies, reflecting on teachers is important for the development of schools. Looking at the world, it is seen that the studies carried out in order to increase the quality of education in hearing impaired schools are supported by technology and contribute to school development [34, 41, 42]. In the education of hearing-impaired children, it is very effective to support knowledge and skills teaching with visual means as much as possible, to organize educational settings and to enable peer interaction. Moreover, when considering the importance of learning by living and the permanence of the learners, the importance of active learning based on practice in the education of hear- 
ing-impaired children is quite striking. Setting up an environment for the education of children with hearing impairment greatly affects the quality of education.

Classroom isolation, proper equipment and devices and children's participation in individual-group hearing aids and educational activities are essential. Hearing impaired children may feel embarrassed and hesitant when they fail in the classroom. At this point, computer-aided materials that hearing-impaired individuals can use on their own initiative provide the opportunity to repeat and provide an individual learning environment, thus providing the individual's self-confidence and influencing learning positively [13]. It is emphasized that effective materials to be prepared for hearingimpaired individuals should be paintings and animations that are front-panel, visualrich, and games-based [21]. For these reasons, in this study, it was aimed that the technologies used in the training of the hearing impaired people were gathered under one heading and presented as technologies for supporting language, speech and academic skills. In this context, research on the use of technology in the education of hearing impaired children in Turkey were examined. It is believed that this study will shed light on the widespread use of technologies used in the training of hearing impaired and the increase of knowledge and skills in using these technologies.

\section{$2 \quad$ Method}

In this study, document analysis technique was used. Document analysis is a technique used in historical and qualitative research. Firstly, the related documents are read and the resulting information is coded. Later, the documents that were coded were brought together and the results given within the scope of the study were removed [28].

\subsection{Data Analysis}

As a result of the analysis of the data, the findings were collected and examined under two categories as the categories used to support the language, speech and academic skills of the hearing impaired.

\section{Results and Discussion}

\subsection{Techniques used to support academic skills in hearing impaired}

It is expected that schools undertaking the duty of hearing impaired individuals to manage according to the conditions of the times and according to the needs of the society, should pursue change, innovation and development studies in the age of information and technology. In this regard, important tasks such as planning and conducting various activities in educational activities are in the controls of the schools. The activities that will be presented to the students are the ones that force their minds, make them think, create a cause- effect relattion and it is expected that it will be in 
the characteristics that reconcile ideas and facts in different forms and comprehend the importance of social values [30]. At the same time, the schools should also benefit from the technology brought by the twenty-first century. The technologies used in the training of disabled students, the hurdles and therefore the learning it is possible to say that students who have problems are effective in solving these problems [29].

In his study Demirhan [10] aimed to examine the effect of information technology on the education of students with hearing impairment. As a result of the study, it was determined that the students in the application group learned lessons faster, so they had more time to practice and repeat [10]. It was determined that the students who benefited from the informatics technologies of the class increased their course successes compared to the students who were educated with classical education and even got more positive results than the students who had some problems and were not inadequate. It has been found that information technology has removed the distraction problem because the students with hearing impairment have increased the interest in the lessons as it has become more fun to learn. In the study of Ciftci [8], the computer-aided teaching material developed has effects on the written expression skills of the students with hearing impairment such as the ability to construct sentences and use timing correctly; aimed to reveal the opinions of Turkish Language and Literature teachers about materials developed by students with hearing impairment. The results of the study showed that the computer aided teaching material positively affected the students' written expression skills such as writing sentences, using correct past, present and future times. In the Cal [6] study, we aimed to reduce the difficulties of understaning and comprehension that individuals who have hearing impairment in our country are suffering from hearing loss by using information technology and distance education. In summary; it is stated that the information technologies used will have some contributions to the students with hearing impairment.

In 2008, a study titled "Utilization of Computer-Assisted Animations in the Process of Education of the Hearing Impaired Individuals" was carried out [21]. In this study, we focused on the possibility of using computer aided animations in the education of the hearing impaired individuals. The opinions of the teachers working in the hearing impairment school have been taken and the solution proposal has been put forward as to which features should be used if animations were to be used. As a result of this research; it has been indicated by teachers that if hearing-impaired students have high computer and technology skills, that computer-aided education is required in all classes, and if curriculum for hearing-impaired students is established, hearingimpaired students can be more successful in class. In addition, it was emphasized that effective software to be prepared for the students with hearing impairment, visual richness, paintings and animations, front-line expression, games-based software should be emphasized. This study will be useful for teachers in special education field to pay attention to what they should do when preparing a software [22]. In addition, Kot, Sonmez, Yikmis and Ince [26] figured out that Touch-Math technique is effective in teaching addition skills to individuals with hearing impairment.

In another study, a web page for the education of the hearing impaired was developed and it was concluded that the hearing impaired individuals were repeatedly taught at distance education and the purpose was to achieve permanence [6]. Dogan 
and Akdemir [12], conducted a "Computer Assisted Instruction in Private Instruction a Three Case Studies". The aim of this study is to examine the process of computer use in the courses of three individuals with intellectual disability, hearing impairment and orthopedic impairment attending he special education and rehabilitation center. As a result, it has been determined that teachers prefer to use educational gaming software with training and rehearsal software in special education and rehabilitation centers. It is seen that individuals with hearing impairment learn words in computer assisted instruction faster than classical methods.

The use of visuals in computer-assisted instruction to explain unknown words (object, meaning, etc.) encountered during reading-writing instruction for individuals with hearing impairment shortens the teaching period. In addition, Karal, Silbir, Bahcekapili and Atasoy [23] put forward that graphical symbols can be included as learning material for the classroom environments of hearing-impaired individuals, and Alternative Communication Systems graphics can be learned by the hearing-impaired individuals and are interesting. In addition, Yaman, Donmez, Avci and Yurdakul [43] investigated the effect of using mobile application in the literacy training of hearingimpaired students and found that mobile application integration in the learning environment increased the interest and motivation of the hearing-impaired students.

Technology in today's world brings many opportunities and convenience for every inhabitant of humanity. The contribution of information and communication technologies to the education and training processes depends on flexibility, saving, efficiency, individuality. In particular, it appears that the main features that hearing impaired people need in the educational process are the planning of individual differences in education and the potential to provide a vital opportunity for hearing impaired people when information and communication technologies are used correctly, which will be the visuality presented by the right technique. This research was conducted to determine how information and communication technologies are used in Hearing Impaired Primary and Secondary Schools.

In the research, 40 students and 15 teachers attending primary and secondary school of Edirne ili Sehit Ogretmen Adnan Tunca Hearing Impaired School participated. The study was designed as a case study of qualitative research methods in terms of the nature and purpose of the study. In order to increase the validity and reliability of the data, data were collected by means of multiple data collecting tools and data diversification was performed. Descriptive analysis and content analysis techniques were used in analyzing the data. According to the results of research, hearing impairments of information and communication technologies are the main teaching tools preferred by teachers in the primary and secondary school teaching process. Teachers also stated that Information and Communication Technologies facilitated the presentation of lessons and increased the motivation of the students. The fact that the technical equipment is old and the students see it as a computer game tool is seen as the main problem. Students also stated that they did not use the computer to study. The creation of a curriculum for hearing impaired students and the production of technological content within the curriculum have been derived from teacher interviews. The results obtained will contribute to the informed use of information and communication technologies in the education of the hearing impaired. Yildirim and 
Saban [44] investigated the effects of computer-assisted geometry teaching on the students 'level of Van Hiele geometry thinking and geometry achievement according to their hearing status, and as a result, it was determined that computer-assisted teaching affects students' geometric academic achievement positively. In addition, Applicants, Teke and Gezgin [39], have conducted a study on the evaluation of educational software and writing designed for the use of hearing-impaired students in their Turkish language education, and have found that applications in which educational software contributes to the teaching of Turkish, well-designed materials such as visual and video.

\subsection{Techniques used to support language and speech skills in hearing impaired individuals}

In a study conducted in 2009, " Learning Environment Design for Improving the Ability of the Hearing Impaired Individuals to Use Additional Abilities in Turkish " was conducted [22]. In this study, a learning environment supported by information and communication technologies was designed to improve the communication skills of the hearing impaired individuals. Goal; is to investigate the appropriateness of a computer-assisted material to help learners to use literacy additions besides literacy skills and to help teach the concepts of cumulative time. As a result of the research; the positive effects of visual items supported by hearing impaired individuals on their literacy skills have been identified. It has been determined that technology-aided applications can address different senses, thereby increasing the hearing impaired individuals' attention and increasing their success rate. The environments in which hearing impaired people are trained should be enriched using appropriate visuals for a more remarkable level of development in order to overcome auditory deficits. Subtitles used for hearing impaired people are used as an alternative to sign language with speech recognition technique especially in live broadcasts. Koruyan [25] explains how to convert texts and instant texts using a web-based Web Speech API, which is supported by Google, in a video that is broadcasted live on a web page with the help of a media server. In the study, the video feed on the web page is provided with the video element that the HTML5 language brings, the web application is written using JavaScript and PHP programming languages and the jQuery library.

Hearing impaired people use sign language to communicate with each other. It is hard for individuals who do not know sign language to communicate with hearing impaired. In this study, it was tried to solve this problem by using developing software Technologies. An integrated system has been developed using text-to-speech technologies and a variety of additional software. Within the framework of a system called " Writing Tracking of Voice Lessons ", a mobile application running on the Android operating system translates users' conversations into texts and is sent instantly to a remote server. The conversation texts stored in the database on the remote server can be monitored instantaneously via Web pages and Android phones with asynchronous data exchange (AJAX) software via the internet.

Within the scope of the thesis, an open Web-based course management system has been developed and all the courses described can be accessed later [5]. Turgut, Bozan 
and Turgut [38] In this research, it was aimed to investigate social media usage habits of hearing-impaired individuals and normal hearing peers for communication purposes. It is possible to say that social media is an important interaction tool for students and it is widely used for communicative purposes when the social media usage, frequency, duration, social media channel, usage purpose and tool variables used by normal hearing and hearing impaired individuals participating in the study are taken together. In addition to this, in this study performed by Uysal, Yilmaz, Eken and Sayar [40], some level of disturbance in pronouns (r, s-ş, z) isolated on mobile basis was determined and some listening exercises It has been proposed. At the end of the relevant stages, the sound will be taken again and the quality will be assessed according to the actual necessity, and if it is recovered, it will be raised to the upper level (from the beginning to the middle level). Thus, it is aimed to provide the development of individuals with impaired pronunciation.

\section{Conclusions and Recommendations}

In this study, impaired hearing technology used in the training were examined in detail the findings of the studies in this area and in Turkey were discussed. Findings obtained from the research were discussed under the headings of academic skills and language and speaking skills. The findings of the research show that the technologies used in the training of hearing impaired people have been used to develop the most literacy skills as academic skills.

There are also researches on mathematical skills. Findings have shown the persistence of the use of technology in the education of hearing impaired and the motivation to increase student motivation. When technology for language and speaking skills is examined, it usually emerges as an alternative method to improve communication skills. Findings show that web-based or mobile applications developed as an alternative to sign language are common.

In addition, the practice of turning conversation into a sentence is also the result of the use of hearing-impaired individuals to support communication skills. As a result, some suggestions for further research and application in the direction of findings obtained from the research are presented:

- For hearing-impaired people, it may be advisable to develop more mobile applications in accordance with the Android and IOS operating system.

- Other academic skills besides reading and writing may also be developed.

- It can be suggested that the developed technologies should be done considering the diagnosis level of hearing impaired individuals.

- Teachers' knowledge and skills about using technology-supported applications for teaching of hearing-impaired students can be increased by organizing in-service training and seminars. 


\section{$5 \quad$ References}

[1] Akcamete, G. \& Gurgur, H. (2009). Isitme yetersizligi olan cocuklarin egitimi. Ankara: Kok Yayincilik.

[2] Aksal, F. A. (2011). Developing evaluative tool for online learning and teaching process. TOJET: The Turkish Online Journal of Educational Technology, 10(3), 69-75.

[3] Aloglu, M. (2004). Egitimde teknolojik egilimler. Ankara: Ankara Universitesi.

[4] Ari, M. \& Bayhan, P., (1999). Okuloncesi donemde bilgisayar destekli egitim. Istanbul: Epsilon Yayinevi.

[5] Cakir, H., Cetin, S. \& Abidin, B. A. S. (2012). Isitme engellilere yonelik dinamik web sayfasinin gelistirilmesi. Bilisim Teknolojileri Dergisi, 6(2), 1-9.

[6] Cal, C. C. (2011). Isitme engelliler icin uzaktan egitim amacli, web tabanli bir arayuz tasarimi ve uygulamasi (Unpublished Master Thesis). Trakya University, Graduate School of Life Scinces, Edirne.

[7] Cavkaytar, A. (2008). Okul-aile isbirligini gelistirme etkinlikleri. Okul, Aile ve Cevre Isbirligi, 1, 77-95.

[8] Ciftci, E. (2009). Isitme engelli ogrenciler icin hazirlanan bilgisayar destekli yazili anlatim becerisi gelistirme materyalinin tasarimi, uygulanmasi ve degerlendirilmesi (Unpublished Master Thesis). Karadeniz University, Graduate School of Life Scinces, Trabzon.

[9] Delen, E. \& Bulut, O. (2011). The relationship between students' exposure to technology and

[10] Demirhan, T. (2008). Bilisim teknolojilerinin isitme engellilerin egitimine etkisinin incelenmesi (Unpublished Master Thesis). Trakya University, Graduate School of Life Scinces, Edirne.

[11] Demirkiran, V. (2005). Ozel egitim kurumlarinda bilgisayar kullanimi ile ozel egitim meslek elemanlarinin bilgisayar destekli egitime iliskin gorusleri ile bilgisayar tutumlarinin belirlenmesi (Unpublished Master Thesis). Marmara University, Institute of Educational Sciences, Department of Special Education, Istanbul.

[12] Dogan, I. \& Akdemir, O. (2015). Ozel egtimde bilgisayar destekli ogretim: Uc durum calismasi. Journal of Higher Education \& Science/Yüksekögretim ve Bilim Dergisi, 5(2), 165-177.

[13] Dogru, S. S. Y. \& Arslan, E. (2008). Engelli cocugu olan annelerin surekli kaygi düzeyi ile durumluk kaygi düzeylerinin karsilastirilmasi. Selcuk Universitesi Sosyal Bilimler Enstitusu Dergisi, 1(19), 543-553.

[14] Gersten, R. \& Baker, S. (1998). Real world use of scientific concepts: Integrating situated cognition with explicit instruction. Exceptional Children, 65(1), 23-25. https://doi.org/10.1177/001440299806500102

[15] Girgin, M. C. (2003). Isitme engelli cocukların egitimine giris. Eskisehir: TC Anadolu Universitesi.

[16] Goldman, S. R. \& Pellegrino, J. W. (1987). Information processing and educational microcomputer technology: Where do we go from here?. Journal of Learning Disabilities, 20(3), 144-154. https://doi.org/10.1177/002221948702000302

[17] Gulbahar, Y. (2005). Egitimde bilgisayar uygulamalari. Ankara: Baskent University.

[18] Gunduz, H. B. (2010). Digital divide in Turkish primary schools: Sakarya sample. TOJET: The Turkish Online Journal of Educational Technology, 9(1), 43-53.

[19] Guzel, H. (2011). Factors affecting the computer usage of physics teachers working at private 
[20] Haksiz, M. (2014). Investigation of tablet computer use in special education teachers' courses. Procedia-Social and Behavioral Sciences, 141, 1392-1399. https://doi.org/10.1016/j.sbspro.2014.05.240

[21] Karal, H. \& Çiftçi, E. (2008). İşitme engelli bireylerin eğitim sürecinde bilgisayar destekli animasyonlardan yararlanma. In 8th International Educational Technology Conference Online papers (Vol. 30, No. 08, p. 2013). Retrieved from http://ietc2008.home.anadolu. edu.tr/ietc2008/86.doc

[22] Karal, H., Silbir, L. \& Kucuksuleyman, N. (2009, May). Designing a learning environment for developing hearing disabled people's skills in using prepositions and tense suffixes in Turkish language. In PROCEEDINGS of 9 th Internatıonal Educational Technology Conference.

[23] Karal, Y., Silbir, L., Bahcekapili E. \& Atasoy, M. (2014). Isitme engelli bireyler icin grafik sembollerle olusturulmus ogrenme materyalleri. Journal of Instructional Technologies \& Teacher Education, 3(3), 9-19.

[24] Kenar, I. (2012). Teknoloji ve derslerde teknoloji kullanimina yonelik veli tutum olcegi gelistirilmesi ve tablet PC uygulamasi. Egitim Bilimleri Arastirmalari Dergisi, 2(2), 123139.

[25] Koruyan, K. (2015). Canli internet yayinlari icin otomatik konusma tanıma teknigi kullanilarak alt yazi olusturulmasi. Bilisim Teknolojileri Dergisi, 8(2), 111-116. https://doi.org/10.17671/btd.31441

[26] Kot, M., Sonmez, S., Yikmis, A. \& Ince, N. C. (2016). Isitme yetersizligi olan ogrencilere eldeli toplama islemi ogretiminde nokta belirleme tekniginin etkililigi. Current Research in Education, 2(1), 17-28.

[27] Lerner, J. W., Mardell-Czudnowski, C. \& Goldenberg, D. (1987). Special education for the early childhood years. US: Prentice-Hall.

[28] Morgil, F. I. \& Yilmaz, A. (1999). Lise X. sınıf kimya II ders kitaplarinin ogretmen ve ogrenci gorusleri acisindan degerlendirilmesi. BAU Fen Bilimleri Enstitusu Dergisi, 1(1), 26-40.

[29] Obiakor, F. E. \& Rotatori, A. F. (2010). Current issues and trends in special education: Research, technology, and teacher preparation. US: Emerald Group Publishing. https://doi.org/10.1108/S0270-4013(2010)19

[30] Ozden, Y. (2002). Egitimde yeni degerler. Ankara: Pegem A Yayincilik.

[31] Reed, P. \& Lahm, E. (2004). Assessing students' needs for assistive technology: A resource manual for school district teams. US: Wisconsin Assistive Technology Initiative.

[32] Salend, S. J. (1998). Effective mainstreaming (3 th. Ed). Upper Sanddle River, New Jersey, Columbus \& Ohio: Merrill Prentice Hall.

[33] Savas, P. (2013) Tablet PCs in English Language Teaching: Benefits and challenges. Global Journal on Technology, 4, 602-607.

[34] Siegel, L. (2000). The educational and communication needs of deaf and hard of hearing children: A statement of principle on fundamental educational change. American Annals of the Deaf, 145(2), 63-78. https://doi.org/10.1353/aad.2012.0813

[35] Tassel-Baska, J., Leonhard, P., Glenn, C., Poland, D., Brown, E. \& Johnson D. (1999). Curriculum review as a catalyst for gifted education reform at the secondary level. Journal of Secondary Gifted Education, 10(4), 473 - 481.

[36] Timur, S., Ege, E. \& Bakis, E. (2006). Engelli kadınlarin ureme sagligi sorunlari ve etkileyen faktorler. CU Hemsirelik Yuksekokulu Dergisi, 10(1), 52-58.

[37] Tufekcioglu, U. (2002). Isitme yetersizlikleri. Eskisehir: Anadolu Universitesi Yayinlari.

[38] Turgut, O. N., Bozan, A. \& Turgut, U. M. (2016). Isitme engelli bireylerin iletisimsel amacli sosyal medya kullanim aliskanliklarinin incelenmesi. KBB-Forum, 15(4), 74-80. 
[39] Uygun, Y., Teke, A. K. \& Gezgin, D. M. (2015). Isitme engelli ogrencilerin Turkce egitiminde kullanilmasi icin tasarlanan bir egitsel yazilim ve yazilimin degerlendirilmesi. Engelsiz Bilisim Kongresi, Manisa.

[40] Uysal, S., Yılmaz, E., Eken, S. \& Sayar, A. (2017). MAHREC: Mobil tabanli harf cikis bozukluklarinin iyilestirilmesi. Lecture Notes in Computer Science, Kocaeli University.

[41] Vesel, J. \& Robillard, T. (2013). Teaching mathematics vocabulary with an interactive signing math dictionary. Journal of Research on Technology in Education, 45(4), 361-389. https://doi.org/10.1080/15391523.2013.10782610

[42] Wicha, S., Sharp, B., Sureephong, P., Chakpitak, N. and Atkins, A. (2012). An animated dictionary for hearing-impaired students in Thailand. Journal of Research in Special Educational Needs, 12(4), 234-244. https://doi.org/10.1111/j.1471-3802.2012.01239.x

[43] Yaman, F., Donmez, O., Avci, E. \& Yurdakul, I. K. (2016). İşitme Engelli Öğrencilerin Okuma-Yazma Eğitiminde Mobil Uygulama Kullanımı. Eğitim ve Bilim, 41(188), 153174.

[44] Yildirim, A. \& Saban, P. A. (2014). Euclidean reality geometri etkinliklerinin isitme durumuna gore ogrencilerin Van Hiele geometrik dusunme duzeylerine ve geometri basarilarina etkisi. Education Sciences, 9(4), 364-379.

\section{Authors}

Meltem Haksiz is with Department of Special Education, Atatürk Faculty of Education, Near East University, P.O. Box: 99138, Nicosia, North Cyprus (email: meltem.haksiz@neu.edu.tr)

Basak Baglama, is with Department of Special Education, Atatürk Faculty of Education, Near East University, P.O. Box: 99138, Nicosia, North Cyprus (email: basak.baglama@neu.edu.tr)

Huseyin Uzunboylu, Department of Educational Sciences, Atatürk Education Faculty, Near East University, P.O. Box: 99138, Nicosia, North Cyprus (email: huseyin.uzunboylu@neu.edu.tr)

Article submitted 25 January 2018. Final acceptance 30 March 2018. Final version published as submitted by the authors. 